\title{
Cost of German Scientific Periodicals
}

\author{
By Dr. Wilfrid Bonser, University Library, Birmingham
}

$\mathrm{T}$ HE increasingly high cost of German medical and biological periodicals is causing the gravest concern to libraries both in Great Britain and in the United States. A letter by me on this subject appeared in NATuRE of April 7, 1928 : the same arguments apply now as then, but the situation has become more acute, especially since the suspension in Great Britain of the gold standard. Not only have the prices continued to increase, but also the economic stringency, which has already been felt by learned institutions in Great Britain during the past year, will in all probability be still more severe during the next few years.

The amount of money which has to be expended in order to obtain the results of German research is totally disproportionate to that speist on the corresponding journals of any other country. The larger German journals are beyond the means of many institutions in Great Britain. The following table, printed in an American pamphlet, will demonstrate this :-

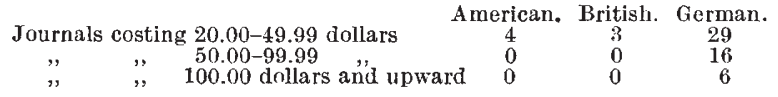

Perhaps the most expensive journal of all is the Zeitschrift für Anatomie und Entwicklungsgeschichte, which is advertised as being published in four volumes a year at the price of about Rm. 175 each. This works out at present rates at $£ 50$ a year. Even then this journal is only Abteilung 1 of a larger journal.

From correspondence which I have had with the United States, it is clear that the breaking point has been reached there as well as in Great Britain. Appropriations there to State-supported institutions are made in many States for a two-year period, and the fact that the next appropriation is now due to be made indicates that, although American libraries have not been forced to reduce their subscriptions by more than twenty per cent at present, they will undoubtedly have to do so far more for the next two years.

It is said that the cost of German periodicals varies with the number of the subscribers. If this is so, it is obvious that the price will be increased from now on in proportion to the number of American libraries which will then be obliged to cancel their subscriptions. The deficiency will most certainly not be made up in the present crisis by an increase in the number of subscriptions in Great Britain.

In these circumstances, it is highly desirable that some accommodation should be reached with the German authors and publishers in order that the results of German research may still be available. A memorandum, issued by the Börsenverein der deutschen Buchhändler "in reply to numerous complaints", is by no means convincing. It is criticised in a most illuminating article by Dr. Georg Leyh, librarian of the University of Tübingen, which appeared in the May number of the Zentralblatt für Bibliothekswesen and shows a German librarian's point of view.

The difficulties may be summarised under the two headings $(a)$ format and $(b)$ contents.

(a) It is impossible for the librarian to estimate the annual cost in advance owing to (1) the fact that the number of volumes in which a journal is published each year often varies considerably ; $(2)$ the practice of issuing monographs as Ergänzungshefte to, or as extra volumes of, important journals-often being included in their running number. An example of this is the Archiv für Entwicklungsmechanik, published by Julius Springer of Berlin. This is announced as appearing in about two volumes a year, the price of each being about Rm. 130. In 1927, in addition to the normal Bde. 109 and 110, two Festschriften appeared as Bde. 111 and 112 , at the cost of $\mathrm{Rm} .104$ and $\mathrm{Rm} .140$ respectively. Such monographs and Festschriften should be issued as independent publications not connected with any journal.

(b) The publishers are being forced to realise, in view of the repeated complaints received from the United States, that it is necessary to reduce the bulk of their periodicals.

The notices issued to contributors to the Zeitschrift für klinische Medizin and to the Deutsches Archiv für klinische Medizin by the publisher (Julius Springer), show how this is to be done. The former notice declares that "the size and price of our periodicals have reached a height which menaces their spread and with it the prestige of German medicine". "Epic breadth accords not with science". The latter notice instructs contributors to practise the greatest brevity in future, "as is done in English writing and in German chemical writing". Extensive introductions containing historical matter will not be accepted. Very few case-histories can in future be printed in detail. Long wordy quotations are to be avoided, and references only are to be given. Articles which have appeared elsewhere will not be accepted. Coloured illustrations can only be included in exceptional cases. The editor is cutting out the less important articles.

It has been the practice in Germany to publish in journals dissertations which have already been printed and distributed by the universities. The Zeitschrift für klinische Medizin requires that they, shall be "freed from historical and literary ballast" before being submitted.

If similar instructions are issued to contributors to all German journals and carried out systematically, the desired effect should be produced, since most of the British and American complaints with regard to the contents of the journals have bren discussed above.

It is to be hoped that those institutions in Great Britain which are contemplating the cancelling of subscriptions will delay doing so in the hope that the Germans will accommodate them in this matter. A radical change of method is required, for by this means alone can German research continue to be available to English readers. The object of this article, apart from stating the position, is to ask readers of NATURE--who are scientific workers rather than librarians-to exercise their influence with their friends in Germany in order to ameliorate the position. If the German writer would be willing to publish only the essentials of his research, the bulk and consequent cost of the German journals could be reduced by a considerable percentage. 